\title{
Physical-Chemical and Bacterial Contamination Levels in Mzinga River Catchments of the Southern Dar es Salaam City, Tanzania: Public Health Implications
}

\author{
Josephat Alexander Saria \\ Department of Environmental Studies, Faculty of Science, Technology and Environmental Studies, The Open University of Tanzania, Dar es \\ Salaam, Tanzania
}

Email Address:

josephat.saria@out.ac.tz

\section{To cite this article:}

Josephat Alexander Saria. Physical-Chemical and Bacterial Contamination Levels in Mzinga River Catchments of the Southern Dar es Salaam City, Tanzania: Public Health Implications. Science Research. Vol. 3, No. 6, 2015, pp. 283-288. doi: 10.11648/j.sr.20150306.13

\begin{abstract}
Water is an appreciated natural resource for the survival of all living organisms. Management of the quality of this precious resource is therefore of special importance. In this study Mzinga River and its tributaries water samples were collected at a weekly interval from $2^{\text {nd }}$ November 2014 to $6^{\text {th }}$ December 2014 and analyzed for physicochemical and bacteriological evaluation of pollutants. Total and faecal bacteria were analyzed using membrane techniques while physical chemical parameters were analyzed using specified standard methods. The water $\mathrm{pH}$ was found to range from $6.09 \pm 0.08$ to $7.05 \pm 0.06$ which is slightly acidic though it is within the acceptable WHO limits of 6.5-8.5. The mean values of ammonium and phosphate varied between $4.50 \pm 0.03 \mathrm{mg} / \mathrm{l}$ to $6.50 \pm 0.04$ and $7.18 \pm 0.27$ to $9.70 \pm 0.12$ respectively. Both of these are higher than Tanzania acceptable limits $(2 \mathrm{mg} / \mathrm{l}$ and $5 \mathrm{mg} / \mathrm{l}$ respectively). The mean result of the analysis of the water samples for total coliform ranges from $14.17 \pm 4.06 \mathrm{CFU} / 100 \mathrm{ml}$ to $486.80 \pm 102.32 \mathrm{CFU} / 100 \mathrm{ml}$, while faecal coliform ranges from $2.78 \pm 1.03$ $\mathrm{CFU} / 100 \mathrm{ml}$ to $120.36 \pm 4.50 \mathrm{CFU} / 100 \mathrm{ml}$. The bacteriological contamination was due to the fact that Mzinga river is passing through a populated urban area thereby more exposed to direct sewage disposal and incoming industrial effluents. These results implicate the probability of people around these areas being prone to water-borne infections such as diarrhea or cholera.
\end{abstract}

Keywords: Cholera, Faecal Coliform, Mzinga, Phosphate, $\mathrm{BOD}_{5}$

\section{Introduction}

Cholera outbreak in Dar es Salaam region started in midAugust 2015. As of early September 2015, the cumulative number of cholera cases in the affected areas was more than 900 cases including 13 deaths. Cholera is a bacterial intestinal infection caused by Vibrio cholerae, transmitted through contaminated food and water [1]. The major features of pathogenesis of cholera are well established. Infection due to $V$. cholera begins with the ingestion of contaminated water or food. It occurs repeatedly in many African countries, mainly due to poor hygiene. It has a short incubation period, from one to five days, with the main symptom being diarrhoea that quickly leads to severe dehydration and death if untreated. From 1970, V. cholera O1 El Tor has gradually spread to most of the continent with case-fatality rates between $4 \%$ and $12 \%$. From 1991 to 1996 , the number of cases remained high and ranged between 70,000 and 160,000 [2]. This was the largest proportion of all reported cholera cases in 1994, and $42 \%$ of all cholera deaths reported globally that year, were in Africa [3].

Most vibrio species are everywhere in estuarine and marine environments and are also found in fresh water provided that there is a certain minimal level of group one element ions [4]. The cholera vibrio, however, was long considered to be an exception, in that it was believed not to be an environmental organism but associated with water only as a result of sewage contamination [5]. Due to that, it has been established that water is important in the transmission of cholera. Water from public supplies, toilets, sewage etc was implicated in the previous pandemics. In the present pandemic, properly treated public water supplies, shallow or deep well water supply, river water supply which are used by majority of Dar es Salaam residents, are not generally considered to be a risk factor [6]. However, serious epidemics of cholera continue to occur in areas where water treatment is poor or sporadic or no treatment at all. Many of the sources that are thought to contribute to the epidemiology 
of diseases associated with raw fruits and vegetables are impacted by ecological conditions that affect survival or growth of pathogenic microorganisms [7]. These sources include raw manure, inorganic amendments, irrigation water and dust [8-10]. The microbial quality of vegetables grown with wastewater is highly alarming [9]. In most of African countries one of the techniques used to kill microbes from vegetables is thermal but for fear of denaturation of beneficial nutrients during heating vegetables are served and consumed raw [10].

In Tanzania, sources of irrigation water are shallow wells, streams and rivers where, large amounts of untreated wastewater are discharged into urban drainage systems and other natural waterways, rivers receive waste from tanneries and textile industries, abattoirs, urban water storm and agricultural runoffs from farming communities along its course $[6,11]$.

River water is the most important and multi-usage component in the outskirts of a cities like Dar es Salaam, where there is no public water supply. It is basically used for drinking, irrigation, fishery and energy production $[5,6,12]$. Although water is a natural resource for sustaining life and environment that we always have, the chemical composition of surface or subsurface water is one of the prime factors on which the suitability of water for domestic, industrial or agricultural purpose depends on its quality [13]. In another study [14], explained different sources of surface water degradation that over the past few decades, the ever-growing population, urbanization, industrialization and unskilled utilization of water resources have led to degradation of water quality and reduction in per capita availability in various developing countries. Like other developing countries of the world, Tanzania is also facing critical water shortage and pollution. Dar es Salaam City receives its water supply from the Ruvu and Kizinga rivers with three water treatment plants, namely, Upper Ruvu, Lower Ruvu and Mtoni, which have a total installed capacity of $605,000 \mathrm{~m}^{3} /$ day $[15,16]$. Mzinga River is one among four major rivers available in watershed in the region including
Mpiji River, which forms the northern boundary of Dar es Salaam, Msimbazi River flows to the north of the city centre and together with Kizinga River, water from these two flows into the harbor area of the city.

Since the city experiences massive population pressure, there is progressive deterioration of water quality due to an increase in domestic, agricultural activities and effluent discharges especially besides the urban rivers. Almost all the freshwater bodies are being polluted by expanding human population and in consequence, industrialization, intensive agricultural practices and discharge of massive amount of waste water etc. which result in deterioration of water quality [17].

Mzinga river water originates from springs in the highland of Msongola. The River has many tributaries but the main ones to be studied are Binguni, Mianzini and Toangoma. Studies on fresh water quality of urban rivers have been conducted by various researchers [18, 19]. However, no inclusive work has been done so far to explore the physicochemical and microbiological characteristics on the water quality of Mzinga river and its tributaries all together. Water quality depletion of Mzinga river is due to improper waste disposal from agro-industrial wastes and environmental degradation consequential to deforestation of river catchments [18].

To avoid any health hazard as the result of consumption of contaminated water, physicochemical analysis of water is unavoidable. Therefore in this study of assessment of the variation of physicochemical parameters of water in Mzinga river from its source to the consumer level is undertaken. The results obtained will be compared to documented Tanzanian standards for water quality and World Health Organization standards, and will be used to provide useful information about the quality of water in Mzinga area.

\section{Material and Methods}

\subsection{Study Area}

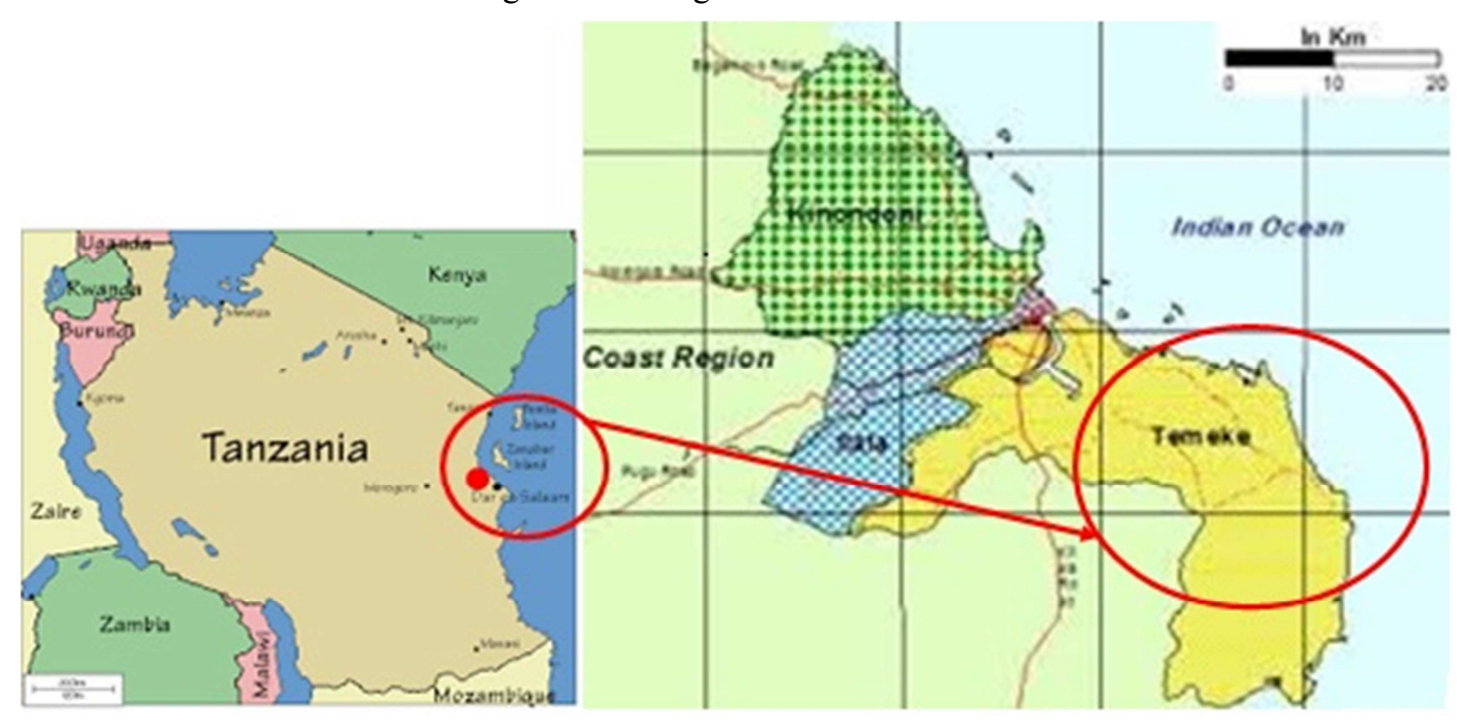

Figure 1. Map of Tanzania Showing Sampling Site. 
Mzinga river is among urban rivers located in Dar es Salaam. It is located in southern part of Dar es Salaam crossing Charambe ward, in southern part is nearby Mbagala Rangi tatu, eastern part of Mbagala kuu and Western part of Tandika. Approximately $18 \mathrm{~km}$ stretch of Mzinga river flows from west to east in the centre of the city and serves as a source of water for agricultural and domestic activities. Together with Kizinga River, they are originated from Pugu Kisarawe hills and consist of sandy sediments. The rivers flow to the north-east direction to Indian ocean. Mzinga has a total length of $10 \mathrm{~km}$ and a catchment of $41 \mathrm{~km}^{2}$ (Figure 1).

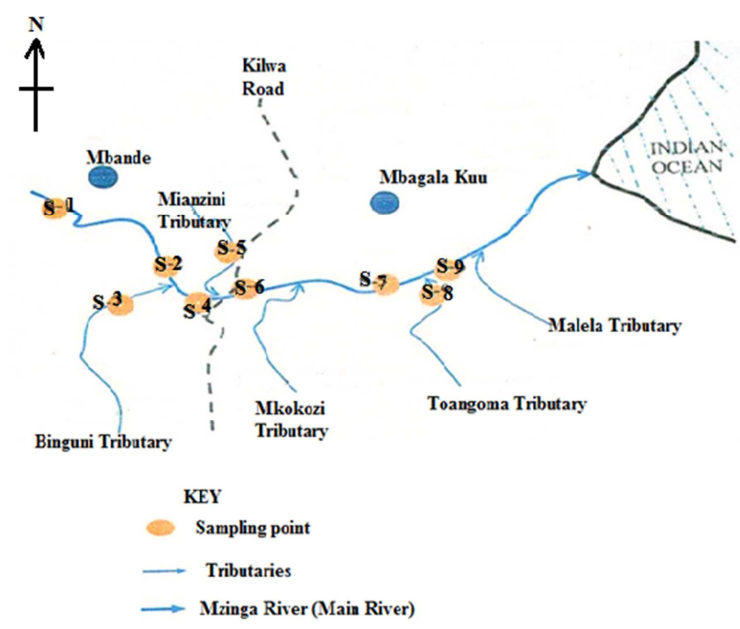

Figure 2. Mzinga River with its Tributaries.

Water sampling was done by grab sampling technique, making sure each tributary was sampled in every visit. The monitoring was done at the weekly interval from $2^{\text {nd }}$ November 2014 to $6^{\text {th }}$ December 2014 . The sampling time was in the morning and stored in $0.5 \mathrm{~L}$ sampling bottles. Sampling was done in the morning so that analysis of the samples can be done in the laboratories the same day and to avoid recreational and other farming activities on the river.

Table 1. Sampling Points.

\begin{tabular}{|c|c|c|}
\hline $\begin{array}{l}\text { Sampling } \\
\text { point }\end{array}$ & Name/ Location & Considerations for selection \\
\hline S-1 & Mbande & $\begin{array}{l}\text { Agricultural activities and blocked } \\
\text { cross-bridge are present }\end{array}$ \\
\hline S-2 & $\begin{array}{l}20 \mathrm{~m} \text { from Binguni } \\
\text { tributary }\end{array}$ & Human settlements \\
\hline S-3 & Binguni tributary & Entrance of Binguni tributary \\
\hline S-4 & Along Mzinga River & $\begin{array}{l}\text { Agricultural activities and human } \\
\text { settlements }\end{array}$ \\
\hline S-5 & Mianzini tributary & Entrance of Mianzini tributary \\
\hline S-6 & Along Mzinga River & Near Car wash \\
\hline S-7 & $\begin{array}{l}15 \mathrm{~m} \text { from mianzini } \\
\text { tributary }\end{array}$ & Human settlements \\
\hline S-8 & Tuangoma tributary & Entrance of Toangoma tributary \\
\hline S-9 & Along Mzinga River & $\begin{array}{l}\text { Agricultural activities and human } \\
\text { settlements }\end{array}$ \\
\hline
\end{tabular}

\subsection{Physicalchemical Analysis}

Parameters such as $\mathrm{pH}$, temperature and DO were analyzed in-situ by using HACH instrument (Sension 15b). Other parameters like Phosphate, Ammonia and BOD were analyzed in the laboratory as per standard methods of water and wastewater examinations [20]. Triplicate in nine (9) sampling points were considered from all tributaries in study area (Fig. 2).

Samples were collected using $500 \mathrm{ml}$ sterile bottles tied on a graduated yard stick so as to sample at about $30 \mathrm{~cm}$ depth. Collected samples were immediately transferred to a cool box containing ice packs until the time of filtration, which never exceed 6 hours after collection [20, 21]. Environmental parameter $(\mathrm{pH})$, were measured in situ at each station using a multi-parameter water quality checker (HoribaU-10, Japan).

\subsection{Microbiological Analysis}

Total and faecal bacteria were analysed using membrane techniques as described in American Health Public Association [21], whereby $100 \mathrm{ml}$ of undiluted and diluted (1 10 times) water sample were filtered through $0.45 \mu \mathrm{m}$ pore size membrane filters. The filters were transferred to two selective media where FC was grown on $\mathrm{m}-\mathrm{FC}$ broth and TC was grown on m-Endo broth. Plates for Faecal coliform (FC) bacteria were incubated at $44.5 \pm 0.5 \mathrm{C}^{\mathrm{o}}$ for $24 \mathrm{hrs}$. FC colonies appeared blue while plates for total coliform (TC) bacteria incubated at $37 \pm 0.5 \mathrm{C}^{\circ}$ for 24 hours were reddish in color.

\section{Results and Discussion}

\subsection{Physical Chemical Parameters}

The $\mathrm{pH}$ is the indicator of acidic or alkaline condition of water status. According to Tanzania Standard permissible limit for drinking purpose ranges from 6.5-8.5 [2, 3]. Analysis of samples in nine sampling sites (Figure $1 \& 2$ ), range from $6.09 \pm 0.08$ to $7.05 \pm 0.06$ which is slightly acidic. The variation of $\mathrm{pH}$ is due to the fluctuation of discharges from the domestic sewage waste.

This shows that water samples have amounts of effluent and impure urban waters hang extremely from amount of free $\mathrm{CO}_{2}$ in water, organic acids and humic acids which originated from agricultural activities closer to sampling points. Also other sources may be from polluted industrial effluents in which they are directed to Mzinga river and hence increases the concentration of $\mathrm{SO}_{2}, \mathrm{NO}_{2}$ etc. For evaluation of water quality is very important confirmation of presence of materials which are created from decomposition of wastes of animal and plant origin. Nitrogen and phosphorus compounds are contributed from fertilizers used in agricultural fields near the river region which seep into the ground water. This reason is comparable with several reports made in literature for contamination of ground water may be due to the seepage of agricultural chemicals, domestic sewage and animal waste [6]. In the present study mean values of ammonium and phosphate varied between $4.50 \pm 0.03 \mathrm{mg} / 1$ and $6.50 \pm 0.04,7.18 \pm 0.27 \mathrm{mg} / 1$ and $9.70 \pm 0.12$ 
respectively. For ammonium, the highest detected value is three times higher than permissible Tanzanian limit for drinking water while for $\mathrm{PO}_{4}{ }^{3-}$ is about twice higher than recommended value [22]. The presence of higher vegetation decomposed in water is possible reason for higher level of nutrients. Similar findings were also found by in another study [23], suggested that sources of nutrients like nitrate, salinity, phosphate and silicate were in ponds with macrophytes, while phosphorus content was higher due to the presence of microcystic bloom.

Table 2. Mean Concentrations of Physical-Chemical Parameters and Bacterial Concentrations from all Sampling Sites.

\begin{tabular}{|c|c|c|c|c|c|c|c|c|c|}
\hline Parameter & S-1 & S-2 & S-3 & $S-4$ & S-5 & S-6 & S-7 & S-8 & S-9 \\
\hline $\mathrm{NH}_{4}^{+}(\mathrm{mg} / \mathrm{l})$ & $6.50 \pm 0.03$ & $5.25 \pm 0.28$ & $5.52 \pm 0.03$ & $6.25 \pm 0.03$ & $5.75 \pm 0.01$ & $5.50 \pm 0.04$ & $6.25 \pm 0.19$ & $4.50 \pm 0.03$ & $6.50 \pm 0.04$ \\
\hline $\mathrm{pH}$ & $6.13 \pm 0.07$ & $6.69 \pm 0.05$ & $6.09 \pm 0.08$ & $6.48 \pm 0.01$ & $7.05 \pm 0.06$ & $6.94 \pm 0.03$ & $6.68 \pm 0.03$ & $6.67 \pm 0.06$ & $6.56 \pm 0.05$ \\
\hline $\mathrm{PO}_{4}{ }^{3-}(\mathrm{mg} / \mathrm{l})$ & $8.50 \pm 0.04$ & $7.18 \pm 0.27$ & $7.27 \pm 0.05$ & $9.20 \pm 0.15$ & $7.61 \pm 0.17$ & $7.29 \pm 0.19$ & $9.15 \pm 0.20$ & $7.31 \pm 0.18$ & $9.70 \pm 0.12$ \\
\hline BOD5(mg/l) & $85.50 \pm 2.04$ & $86.01 \pm 0.63$ & $107.10 \pm 3.19$ & $89.30 \pm 0.42$ & $110.30 \pm 1.03$ & $89.20 \pm 0.41$ & $90.30 \pm 5.70$ & $90.80 \pm 1.17$ & $85.20 \pm 0.63$ \\
\hline DO (mg/l) & $4.86 \pm 0.06$ & $4.68 \pm 0.09$ & $3.78 \pm 0.04$ & $4.32 \pm 0.05$ & $3.43 \pm 0.05$ & $4.32 \pm 0.05$ & $4.33 \pm 0.02$ & $4.33 \pm 0.04$ & $4.85 \pm 0.06$ \\
\hline $\begin{array}{l}\text { TC } \\
(\mathrm{CFU} / 100 \mathrm{~mL})\end{array}$ & $14.17 \pm 4.06$ & $226.33 \pm 2.06$ & $83.63 \pm 12.32$ & $486.80 \pm 102.32$ & $76.80 \pm 24.31$ & $118.80 \pm 45.67$ & $217 \pm 27.21$ & $162.36 \pm 5.79$ & $220.80 \pm 28.03$ \\
\hline
\end{tabular}

Dissolved oxygen (DO) is a very crucial parameter for the survival of aquatic organisms and is used to evaluate the degree of freshness of water/river. The dissolved oxygen (DO), which acts as an indicator of the oxygen status of the water body fluctuated between $3.43 \pm 0.05 \mathrm{mg} / \mathrm{l}$ and $4.86 \pm 0.06$ $\mathrm{mg} / \mathrm{l}$ in the river stretch under study. Large depletion of DO is indicative of the presence of considerable amount of biodegradable organic matter in the river water [8]. The minimum level of DO $3.43 \pm 0.05 \mathrm{mg} / \mathrm{l}$ was found in $\mathrm{S}-5$ the entrance of Mianzini tributary which received municipal sewage and domestic waste water.

The $\mathrm{BOD}_{5}$ is referred as amount of used oxygen for biochemical decomposition of organic matter in water. $\mathrm{BOD}_{5}$ is used for determination of relative demand of oxygen for effluents and discard waters because ir is an indicator of pollution level of waters. In this study, $\mathrm{BOD}_{5}$ values varied from $85.20 \pm 0.63 \mathrm{mg} / 1$ to $110.30 \pm 1.03 \mathrm{mg} / \mathrm{l}$. These values are extremely higher than Tanzanian and WHO standards limits of $6.0 \mathrm{mg} / 1$ and $5.0 \mathrm{mg} / 1$ respectively $[3,22]$. It has been established before [24] that if the amount of decomposing organic material is too high, it means $\mathrm{BOD}_{5}$ is also high
(Table 3).

Table 3. Status of Water Sample in Terms of $B O D_{5}$.

\begin{tabular}{ll}
\hline BOD Level $(\mathbf{m g} / \mathbf{l})$ & Status of the Sample \\
\hline $1-2$ & Clean water with little organic waste \\
$3-5$ & Moderate clean with some organic waste \\
$6-9$ & A lot of organic materials and bacteria \\
$>10$ & $\begin{array}{l}\text { Very poor water quality. Large amount of organic } \\
\text { material in water }\end{array}$ \\
\hline
\end{tabular}

From Table 2, all water from the nine points' is highly contaminated and unfit for human consumption. Generally, from analyzed samples (Figure 3) when $\mathrm{BOD}_{5}$ levels are high, the level of DO is small. This is because the demand for oxygen by the bacteria is high and they consuming oxygen from the that dissolved in the water (Table 3). If there is no organic waste present in the water, there won't be as many bacteria present to decompose it and thus the $\mathrm{BOD}_{5}$ will tend to be lower and the DO level will tend to be higher.

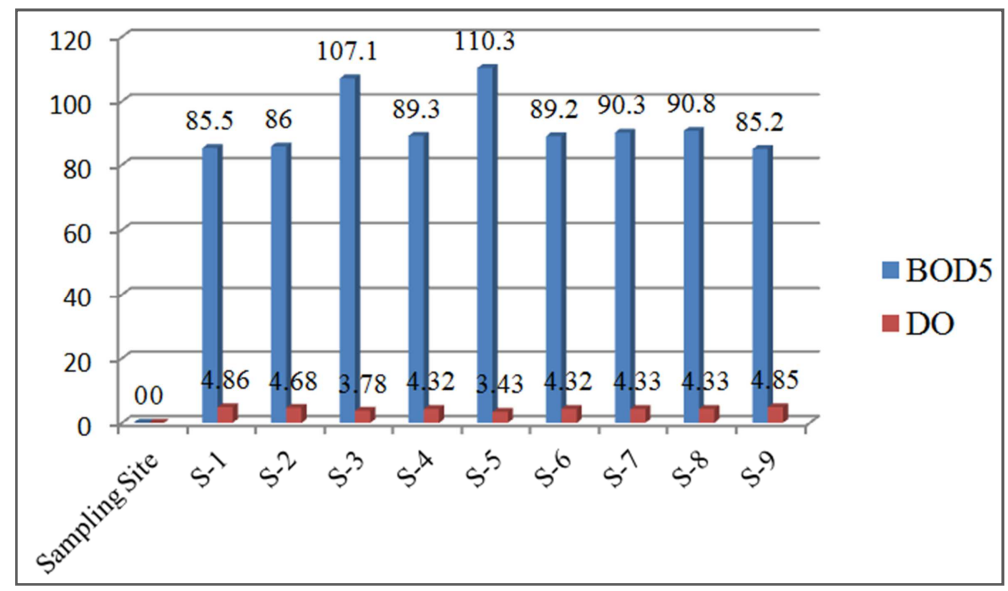

Figure 3. Comparison of levels of $\mathrm{BOD}_{5}$ and DO from Sampling Sites.

\subsection{Bacterialogical Contamination}

From the health point of view, the most important characteristic of good quality water is obviously an absence of pathogenic organisms [19]. By convention, water contamination is considered to be the introduction or release 
into water organisms or toxic substances that render it unfit for human consumption [25]. Meanwhile, water bodies polluted by fecal discharge from man and other animals may transport a variety of human pathogens. The presence of faecal coliform bacteria indicates that your water is contaminated with faeces or sewage, and it has the potential to cause diseases like cholera. Both WHO and Tanzanian standards suggest zero bacteria values in drinking water.

The mean result of the analysis of the water samples ranges from $14.17 \pm 4.06 \mathrm{CFU} / 100 \mathrm{ml}$ to $486.80 \pm 102.32 \mathrm{CFU} / 100 \mathrm{ml}$ for total coliform, while faecal coliform ranges from $2.78 \pm 1.03$ CFU/100ml to $120.36 \pm 4.50 \mathrm{CFU} / 100 \mathrm{ml}$. The detection of high number of bacteria was due to the fact that Mzinga river passes through a populated urban area thereby more exposed to direct sewage disposal and incoming industrial effluents as was reported before [18]. It is evident that several human activities, (Table 1) could also result into further contamination including the use of on-site latrines which was observed along the river. Other human activities such as direct bathing are known to contribute to the high amounts of faecal indicator bacteria loads in the near shore waters [26]. Another possible source of contamination identified by other researchers at Mzinga river is the direct defecation in the mangrove forest in this site as also reported by [18].

Human diseases can occur due to consumption of crops that have been irrigated with polluted water. Crops that are eaten raw (e.g., celery, lettuce, tomatoes, peppers) are especially dangerous for the transmission of disease-causing organisms. Because some bacteria will desiccate (or dry-out) and die from prolonged exposure to air, the risk for illness can be decreased by delaying the harvest and consumption of crops [3].

Several studies throughout the world have demonstrated a very close relation between the consumption of fruits and vegetables irrigated with raw wastewater or polluted river water and many food borne diseases like gastroenteritis, cholera, chemical toxicity etc [8, 27]. River water used in irrigation is largely considered an inevitable option to compensate water shortages in developing countries especially Tanzania. It was observed during sampling that the irrigation of vegetables especially African spinach (Amaranth sp.), Chinese cabbage (Brassica chinensis), Cowpea leaves (Vigna unguiculata), Leafy cabbage (Brassica rapa), Lettuce (Lactuca sativa) and Pumpkin leaves (Moschata cucurbita). All nine samples from sampling site met the international standards for the guideline limit for faecal coliform bacteria in unrestricted irrigation of crops likely to be eaten raw where the levels of faecal coliform counts observed were lower than $200 \mathrm{CFU} / 100 \mathrm{ml}$ recommended for irrigation of vegetable [2]. Hence these waters are not suitable for human consumption but can be used for irrigation of vegetable and salad crops without prior treatment.

\section{Conclusion and Recommendation}

The results suggest that sources of contamination are due to the influence of environmental factors. Generally the bacteriological indicators in the studied waters along the coast of Tanzania were extremely higher than the acceptable standards according to WHO and TBS indicating high risk situation for consumption hence be a good source of cholera. Further studies and monitoring programs are recommended to substantiate the current results. It is recommended that the government enforce strict rules and legislation on adequate treatment of wastewater and effluents before discharge to the environment. Proper washing and disinfection of vegetables before consumption is strongly advised.

\section{Acknowledgement}

My sincere thanks are due to Head of Department Environmental Studies Ms Isabela Thomas and Dr G. F. Mhando (MD) from Amana Hospital for their constant encouragement in this works.

\section{References}

[1] Freitas A. (2013), Water as a Stress Factor in Sub-Saharan Africa http://www.iss.europa.eu/uploads/media/Brief 12.pdf (Accessed on $13^{\text {th }}$ June 2015).

[2] WHO (2011), Guidelines for Drinking-Water Quality. $4^{\text {th }}$ edition. World Health Organization, Geneva.

[3] WHO (1997) WHO Guide Lines for the Safe Use of Wastewater, Excreta and Grey water: Wastewater Use in Agriculture, Volume II, World Health Organization, France, $22 \mathrm{p}$.

[4] Wright, J. A, Yang, H., Rivett, U. and Gundry, S. W. (2012), Public Perception of Drinking Water Safety in South Africa 2002-2009: A Repeated Cross-Sectional Study, BMC Public Health 12: 556-564.

[5] Nelson, A. W., Feazel, L. M., Robertson, C. E., Spear, J. R. and Frank, D. N. (2012), Microbiological Water Quality Monitoring in a Resource-Limited Urban Area: A Study in Cameroon, Africa, The Journal of Public Health in Africa 3(2) 80-85.

[6] Napacho, Z. A. and Manyele, S. V. (2010), Quality Assessment of Drinking Water in Temeke District (Part II): Characterization of Chemical Parameters, African Journal of Env Sc and Tech 4(11), 775-789.

[7] Vital, M., Füchslin H. P., Hammes F., Egli, T. (2007), Growth of Vibrio Cholerae O1 Ogawa Eltor in Freshwater, Microbiology, 153 (Pt 7): 1993-2001.

[8] Selma, M.V., Allende, A., Lopez-Galvez, F., Elizaquivel, P., Aznar, R. and Gil, M., I. (2007), Potential Microbial Risk Factors Related to Soil Amendments and Irrigation Water of Potato Crops, Journal of Applied Microbiology, 103: 25422549 .

[9] Ajayi, A.O., Balogun, S.A. and Adegbehingbe, K. (2008), Microorganisms in the Crude Oil- Poducing Areas of Ondo State, Nigeria. Scientific Research and Essay 3(5) 174-179.

[10] Udousoro, I. I., Ekop, U. R. and Udo, J. E. (2013) Effect of Thermal Processing on Anti-nutrients in Common Edible Green Leafy Vegetables Grown in Ikot Abasi, Nigeria, Pakistan Journal of Nutrition 12(2): 162-167. 
[11] Taylor, B., (2009) Addressing the Sustainability Crisis: Lessons from Research on Managing Rural Water Projects; Water Aid.

[12] Atio, A. (1997), Special Issue: Biological Monitoring in Occupational and Environmental Health, Sci. Total Environ., $199,1-226$

[13] Maheshwari, M. R. C. (2006), Fluoride in Drinking Water and its Removal, Journal of Hazardous Materials, B137: 456-463

[14] Kass, Y. Y.; Gavrieli, A. and Vengosh, A. S (2005), The Impact of Freshwater and Wastewater Irrigation on the Chemistry of Shallow Groundwater: A Case Study from the Israeli Coastal Aquifer, J. Hydrol. 3(1-4) 314-331.

[15] Japan International Cooperation Agency (JICA) (1991). Rehabilitation of Dar es Salaam Water Supply System in the United.

[16] Howard, H. (1967), Future Sources of Water Supply for Dar es Salaam. Consultancy Report, Dar es Salaam, Tanzania.

[17] Raja, P. Muhindhar A. A., Elangovan, R. and M. Palanivel (2008), Evaluation of physical Physical and chemical Chemical parameters Parameters of River Kaveri, Tiruchirappalli, Tamil Nadu, India, Journal of Environmental Biology, 29(5) 765-768.

[18] Abbu, A. A. and Lyimo, T. J. (2007), Assessment of Faecal Bacteria Contamination in Sewage and Non-sewage Impacted Mangroves Ecosystem along the Coast of Dar es Salaam, Tanzania Journal of Science, 33, 27-40.

[19] Richard, F., McGary, M., Mara, D. (1977), Water, Wastes and Health in Hot Climates, John Wiley and Sons Ltd., New York.
[20] APHA, (2005), Standard Methods for the Examination of Water and Wastewater, 18th Ed., American Public Health Association (APHA), American Water Works Association (AWWA) and Water Pollution Control Federation (WPCF), Washington, D.C.

[21] Angerer, J. K. and Schaller, K. H.(1995), Analyses of Hazardous Substances in Biological Materials, Vol. 1, VCH, Weinheim, Germany.

[22] TBS (Tanzania Bureau of Standard) (1997), Finalized Tanzania Standard Specifications for Natural Mineral Water.

[23] Attab, A. (1995), Physico-chemistry of Four Lentic Freshwater Bodies Infested by Varying Dominant Biota with Emphasis on the Impact and Causes of Proliferation of Dominant Biota, IJEP, 8, 99-104.

[24] Alam, J. B.; Islam, M. R.; Muyen, Z. Mamun, M. and Islam, S. (2007), Water Quality Parameters along Rivers, Int. J. Environ. Sci. Tech., 4 (1): 159-167.

[25] Gordon, M.F., John, C. G., Daniel, A. G. (1966), Water and Waste Water Engineering. , John Wiley and Sons Inc. New York.

[26] Dwight, R., Semenza, J, Barker, D. and Olson, B. (2002), Association of Urban Run-off with Coastal Water quality in Orange Country, California, Water Environ Res. 74, 82-90.

[27] Scott, C. A., Faruqui, N. I. and Raschid-Sally, L. (2004), Wastewater use in Irrigated Agriculture, Management Challenges in Developing Countries p.110, in Scott, C.A., Faruqui, N.I. and Raschid-Sally, L. (ed) Wastewater Use in Irrigated Agriculture: Confronting the Livelihood and Environmental Realities, CABI Publishing, Oxford Shire, United Kingdom. 